\title{
C. - Autres thèmes
}

Other topies

\section{ÉVOLUTION DE L'UTILISATION DU LACTOSÉRUM SEC DANS LES RÉGIMES de SEVRAge PRÉCOCE DU PORCELET et durant la péRIOde de CROISSANCE-FINITION}

\author{
C. FÉVRIER et A. AUMAITRE \\ Station de Recherches sur l'Élevage des Porcs, \\ Centre national de Recherches zootechniques, I. N. R. A., \\ 78350 Jouy en Josas \\ RÉ,SUMÉ
}

Dans une expérience portant sur 78 porcelets sevrés à 5 semaines, on a comparé l'efficacité alimentaire de 3 régimes renfermant $5 \mathrm{p}$. roo de lait écrémé ou ro p. roo ou 20 p. roo de lactosérum sec; puis l'incidence de l'emploi de ces régimes sur l'utilisation ultérieure de régimes riches en lactosérum sec (6o et $30 \mathrm{p}$. Ioo) ou sans produit laitier.

Chez les porcelets, les meilleurs résultats entre 5 et io semaines ont été obtenus avec le régime renfermant io p. Ioo do sérum sec; la dureté du granulé obtenu avec le régime à $20 \mathrm{p}$. Ioo de sérum semblant être le facteur limitant de la consommation journalière d'aliment.

Pour les porcs en croissance, la qualité du régime de sevrage n'a eu pratiquement aucune influence sur l'utilisation des régimes riches en lactosérum, mais en début de période de croissance le taux de $3^{\circ} \mathrm{p}$. Ioo de sérum se révèle être très significativement meilleur que o ou $60 \mathrm{p}$. Ioo. Par la suite cette supériorité par rapport au régime témoin sans sérum s'amenuise tandis que l'efficacité alimentaire du régime à 60 p. roo de sérum se dégrade. Ceci confirme donc les résultats précédemment acquis en ce qui concerne la période de croissance-finition et montre qu'il est illusoire de vouloir obtenir une meillcure utilisation des régimes riches en lactosérum par le maintien d'une alimentation lactée lors du sevrage.

\section{SUMMARY}

\section{UTILIZATION OF DRY WHEY IN THE EARLY WEANING DIETS OF PIGLETS AND DURING THE GROWING-FINISHING PERIOD}

In a trial with 78 piglets weaned at 5 weeks, the feed efficiencies of 3 diets containing 5 p. Ioo skim-milk or to or $20 \mathrm{p}$. Ioo dry whey were compared and the repercussion of these diets on the further utilization of rich dry whey diets ( 30 and $60 \mathrm{p}$. I00) or diets without milk products was investigated. 
In piglets, the best results were obtained between 5 and Io weeks with the diet containing Io p. Ioo dry whey; the consistency of the pellets prepared with the $20 \mathrm{p}$. Ioo whey diet seemed to be the limiting factor of the daily feed intake.

As regards the growing pigs, the quality of the weaning diet did not have any effect on the utilization of rich whey diets, but in the beginning of the growth period, the level of $30 \mathrm{p}$. roo whey appeared to be significantly better than o or $60 \mathrm{p}$. Ioo. Later on this superiority, compared with the whey free control diet, became less marked while the feed efficiency of the $60 \mathrm{p}$. 1oo whey diet decreased. This fact confirms the previously obtained results concerning the growing-finishing period and shows that a better utilization of the diets rich in whey, by maintaining milk feeding at weaning, is illusory.

\title{
UTILISATION DES DÉCHETS DE BANANE "POYO " PAR LE PORC EN CROISSANCE AUX ANTILLES FRANÇAISES
}

\author{
B. SÈVE, J. LE DIVIDICH et I. CANOPE \\ Station de Recherches sur l'Élevage des Porcs, \\ Centre national de Recherches agronomiques, I. N. R. A., \\ 78350 Jouy en Josas \\ Centre de Recherches des Antilles-Guyane, I. N. R.A., \\ Petit-Bourg - (Guadeloupe)
}

\section{RÉSUMÉ}

Au cours de deux essais simultanés au sol et en cage de digestibilité, on a comparé les valeurs alimentaires de deux types d'ensilage de déchets de banane "Poyo \#, à celle du produit frais chez le porc en croissance-finition (3o à go kg) alimenté deux fois par jour. Lorsqu'on ensile la banane mûre (mûrissement artificiel à l'acétylène) les pertes de matières sèche en un mois de conservation sont considérables ( $37 \mathrm{p}$. Ioo) ; elles tombent à I6 p. Ioo avec la banane broyée verte. La digestibilité de la matière sèche est plus faible avec les produits ensilés verts $(80,6)$ ou mûrs $(77,3)$ qu'avec le produit frais $(83,4)$. Déjà faible avec la banane ensilée verte $(72,2)$, la digestibilité des matières azotées tombe à 68,4 avec la banane ensilée verte et à 64,2 avec la banane ensilée mûre. De même la rétention relative d'azote qui est de $58,4 \mathrm{p}$. Ioo avec le produit frais tombe à $53,8 \mathrm{p}$. Ioo avec l'ensilage vert et à 47,5 p. Too avec l'ensilage mûr.

Grâce à une meilleure valorisation de l'aliment complémentaire due au moindre encombrement de la ration, les performances obtenues avec l'ensilage de banane verte (28,5 p. Ioo de MS) égalent celles obtenues avec le produit frais ( 22 p. Ioo de MS). En présence de banane ensilée mûre (22 p. Ioo de MS), la croissance est significativement ralentie.

L'augmentation de la durée d'engraissement de 30 à $90 \mathrm{~kg}$ par rapport à un régime témoin se chiffre à $3^{6}, 4^{2}$ et $4^{8}$ jours respectivement pour les produits frais, ensilés verts et ensilés mûrs dans le cas d'une distribution minimum d'aliment complémentaire. Les quantités correspondantes de déchets consommés par porc produit s'élèvent respectivement à 648,839 et I oro $\mathrm{kg}$, pertes de conservation comprises, permettant ainsi l'économie de $150 \mathrm{~kg}$ d'un aliment concentré sans protéines. 